九州大学学術情報リポジトリ

Kyushu University Institutional Repository

\title{
Photosynthesis, Transpiration, Dry Matter Accumulation and Yield Performance of Mungbean Plant in Response to Water Stress
}

Hamid, Abdul

Agronomy Department, Institute of Postgraduate Studies in Agriculture

Kubota, Fumitake

Laboratory of Practical Botany, Faculty of Agriculture, Kyushu University

Agata, Waichi

Laboratory of Practical Botany, Faculty of Agriculture, Kyushu University

Morokuma, Masahiro

Laboratory of Practical Botany, Faculty of Agriculture, Kyushu University

https://doi.org/10.5109/23953

出版情報: 九州大学大学院農学研究院紀要. 35 (1/2)，pp.81-92，1990-12. Kyushu University バージョン：

権利関係 : 


\title{
Photosynthesis, Transpiration, Dry Matter Accumulation and Yield Performance of Mungbean Plant in Response to Water Stress
}

\author{
Abdul Hamid*, Fumitake Kubota, Waichi Agata and \\ Masahiro Morokuma \\ Laboratory of Practical Botany, Faculty of Agriculture, \\ Kyushu University, Hakozaki, Fukuoka 812, Japan
}

(Received July 31, 1990)

\begin{abstract}
Photosynthetic components, dry matter production and yield in water stressed mungbean (Vigna radiata (L.) Wilczek) plants were compared with those of non-stressed or well watered plants grown in a semi-controlled environment. Mungbean plants were subjected to variable water stress at three growth stages viz. from pre-flowering, flowering and pod development to harvest, The effect of soil moisture on the grain yield varied with the severity of stress and stage of crop growth. Water deficits during pre-flowering to harvest affected most the crop production, photosynthetic rate and the factors related. Soil moisture saturation reduced the yield to about $6 \%$ of that of well watered plants. The yield loss was primarily caused by the reduction of canopy development, inhibition of photosynthetic rate and lower dry matter production. Optimum soil moisture for the growth and photosynthetic rate in mungbean plant was found around $0.15 \mathrm{~cm}^{3} / \mathrm{cm}^{3}$.
\end{abstract}

\section{INTRODUCTION}

Mungbean(Vigna radiata (L.) Wilczek) is an important grain legume in tropical and sub-tropical Asia. The crop grown under rain-fed conditions frequently suffers water stress in the process of its life cycle. The influence of water stress on physiological processes in plants has been reviewed extensively (Hsiao, 1973 ; Schulze, 1986). Muchow (1985) reported that mungbean plants subjected to severe water deficits were about $40 \%$ less productive than in well watered plants.

Water stress affects crop growth and yield production through the reduction of canopy development (Kriedemann, 1986) and inhibition of photosynthesis (Boyer, 1976). Several workers, Ehleringer and Cook (1984) and Grieu et al. (1988) showed that soil water content affected the gas exchange of plant leaf, although the mechanism of these effects has not been clearly explained (Schulze, 1986 ; Kaiser, 1987). While the reductions of photosynthetic and transpiration rates were reported to be directly associated with the aperture of stomata (Ghorashy et al., 1971 ; Johnson et al., 1974 ; Rao and Bhatt, 1988).

Leaf photosynthetic and transpiration rates are interrelated and might be influenced in a similar trend by the environmental factors like soil moisture status, light, temperature etc. (Agata et al., 1985). Leaf conductance (gl) to the diffusion of CO, is

*Agronomy Department, Institute of Postgraduate Studies in Agriculture, Salna, Gazipur 1703, Bangladesh 
commonly used as an indicator of crop water status (Muchow, 1985) and photosynthetic activity (Wong et al., 1979).

The aim of the present work is to assess the effect of water stress imposed at different growth stages on photosynthesis, transpiration, leaf conductance and consequential growth response of mungbean plants.

\section{MATERIALS AND METHODS}

Mungbean seeds (cv. MB 7715) obtained from Bangladesh Agricultural Research Institute Joydebpur were planted on three different dates (15, 22, and 29 June, 1988) at the water-level controllable plot $(2 \mathrm{~m} \times 4 \mathrm{~m})$ in the vinyl house set in the field of Kyushu University. Plants were grown in rows of $30 \mathrm{~cm}$ apart at an adequate soil moisture until the beginning of treatment on Aug. 2. Compound fertilizer (16:16:16 NPK) of 20 $\mathrm{g} / \mathrm{m}^{2}$ were applied before planting the seeds. At the first trifoliate stage, seedlings were thinned to maintain a density of 33 plants per square meter (one plant/30 cm x $10 \mathrm{~cm})$.

Plants were light-irrigated 2 or 3 times a day and grown uniformly until the start of treatments. The soil used was sandy loam with low water holding capacity. The experimental plots were constructed by concrete walls around to simulate variable soil moisture gradients. Four soil moisture levels could be created by maintaining height of the water level in the interconnected water tank adjacent to each of the plots.

The soil moisture treatments imposed were as follows :

(1) High moisture (hm) : the water tank adjacent to the plot was filled up to the brim to maintain the soil profile saturated or nearly saturated.

(2) Adequate moisture (am) : the tank was half filled to maintain the water level $50 \mathrm{~cm}$ below the soil surface. This created a capillary flow sufficient to supply the adequate amount of transpirable water to the root zone (Hamid et al., 1988).

Table 1. Outline of the experimental schedule.

\begin{tabular}{|c|c|c|c|}
\hline Sowing time & $\begin{array}{l}\text { Growth stage at } \\
\text { start of water } \\
\text { treatment (Aug. 2) }\end{array}$ & $\begin{array}{l}\text { Soil moisture } \\
\text { treatment }\end{array}$ & $\begin{array}{l}\text { Abbrebiation } \\
\text { mark of plot }\end{array}$ \\
\hline June 15 & Pod-development & $\begin{array}{l}\text { High moisture } \\
\text { Adequate moisture } \\
\text { Light drought } \\
\text { Heavy drought }\end{array}$ & $\begin{array}{l}\text { PD-hm } \\
\text { PD-am } \\
\text { PD-Id } \\
\text { PD-hd }\end{array}$ \\
\hline June 22 & Flowering & $\begin{array}{l}\text { High moisture } \\
\text { Adequate moisture } \\
\text { Light drought } \\
\text { Heavy drought }\end{array}$ & $\begin{array}{l}\text { FL-hm } \\
\text { FL-am } \\
\text { FL-ld } \\
\text { FL-hd }\end{array}$ \\
\hline June 29 & R-e-flowering & $\begin{array}{l}\text { High moisture } \\
\text { Adequate moisture } \\
\text { Light drought } \\
\text { Heavy drought }\end{array}$ & $\begin{array}{l}\text { PF-hm } \\
\text { PF-am } \\
\text { PF-Id } \\
\text { PF-hd }\end{array}$ \\
\hline
\end{tabular}

\footnotetext{
*Treatment period was 38 days from Aug. 2 to Sept. 9 (harvest day).
} 
(3) Light drought (ld): the tank was partially filled to maintain the water level $100 \mathrm{~cm}$ below the soil surface.

(4) Heavy drought (hd) : no irrigation except for twice light water sprinkling on Aug. 7 and 23.

Outline of the treatment schedule in this experiment is shown in Table 1. At the start time of water treatments (Aug. 2), mungbean plants sown on 15, 22, and 29 June grew to the stage of pod development (PD), flowering (FL) and pre-flowering (PF), respectively. The water treatments were continued during 38 days from Aug. 2 to Sept. 9 (harvest time). These experimental plots were divided into the four small plots with the four different soil moisture treatments. Hence the experiment was designed by $3 \times 4=12$ different treatments.

Sample plants were harvested together with roots on four occasions (Aug. 2, 16, 23 and Sept. 9) to determine the dry matter weight and leaf area development and investigate the root system.

At each sampling time, five plants were harvested from each of 12 plots and segmented into the different components. Leaf area of individual plant was determined automatically using a leaf area meter. The segmented plant parts were dried at $80^{\circ} \mathrm{C}$ to a constant weight to get the dry matter.

After the start of treatments, change in soil moisture of the upper layer $(\mathrm{O}-15 \mathrm{~cm})$ was determined gravimetrically at regular intervals until the final harvest.

$\mathrm{CO}$, gas exchange rates were measured twice, on Aug. 20 and Aug. 30, using the single leaf of plants. Net photosynthetic rate, transpiration rate and leaf conductance were determined by a portable infra-red gas analyzer and data logger (ADC, UK).

Measurements were made with at least three different leaves of five separate plants using a clamp-on leaf chamber (leaf area $6.25 \mathrm{~cm}^{2}$ ) under high solar radiations over $1000 \mu \mathrm{mol} / \mathrm{m}^{2} / \mathrm{s}$ between $11.00 \mathrm{hrs}$ and $13.00 \mathrm{hrs}$. Readings were taken when a steady-state condition had been reached several minutes after closing the Ieaf chamber. Rates of net photosynthesis and transpiration, leaf conductance and the other parameters related were calculated following Von Caemmerer and Farquhar (1981).

\section{RESULTS}

\section{Soil moisture regulation :}

Soil moisture of the water cut plots declined quickly for the initial few days and slowly afterward. Table 2 gives the soil moisture contents on the two days, Aug. 20 and Aug. 30, both of which correspond to the days when the gas exchange rates were

Table 2. Status of soil moisture content at different water stress treatments. Soil moisture contents were average values at the upper layer $(\mathrm{O}-15 \mathrm{~cm})$ of the soil profile.

\begin{tabular}{lccc}
\hline Soil moisture level & \multicolumn{3}{c}{ Soil moisture content $\left(\mathrm{cm}^{3} / \mathrm{cm}^{3}\right) \mathbf{x} 10^{-2}$} \\
Aug. 30 & Mean \pm S. D. \\
\hline High moisture & 20 & 21.42 & $23.06 \pm 4.08$ \\
Adequate moisture & 15.56 & 15.49 & $15.67 \pm 0.37$ \\
Light drought & 10.75 & 10.36 & $10.56 \mathrm{t} 0.45$ \\
Heavy drought & 6.78 & 5.50 & $6.14 \pm 1.35$ \\
\hline
\end{tabular}




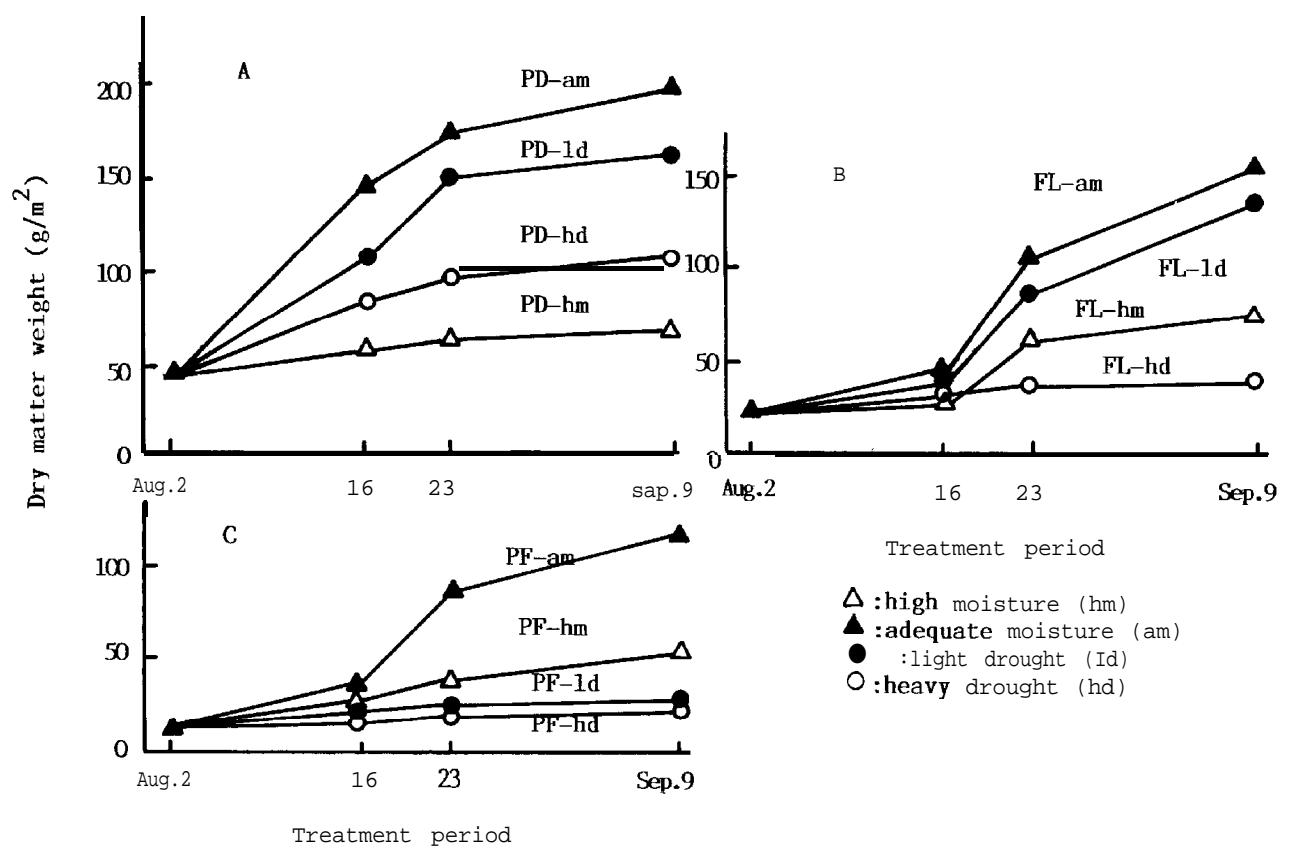

Fig. 1 Time course change in dry matter weight in plants grown under different soil moisture conditions. A, soil moisture treament from pod development stage to harvest ; $\mathrm{B}$, from flowering stage to harvest and $\mathrm{C}$, from pre-flowering to harvest.

measured. Soil moisture contents were $0.2306 \pm 0.0408,0.1567 \pm 0.0037,0.1056 \pm 0.0045$ and $0.0614 \pm 0.0135\left(\mathrm{~cm}^{3} / \mathrm{cm}^{3}\right)$ at the level of high $(\mathbf{h m})$ and adequate moisture (am), and light (ld) and heavy drought (hd), respectively. The standard deviations of soil moisture content were quite small, which indicated the soil moisture status could be kept almost stable in each plot.

\section{Dry matter accumulation :}

Effect of soil moisture on the total dry matter accumulation of mungbean plants is depicted in Fig. 1. Whole plant dry matter increased with time, although the trend of increase varied greatly depending on the soil moisture levels and growth stages of plants.

Higher dry matter weights were given under the adequate moisture (am) condition. For the final dry matter weights, the largest value, $190 \mathrm{~g} / \mathrm{m}^{*}$, was given in PD-am plot and those in FL-am and PF-am plots were $155 \mathrm{~g} / \mathrm{m}^{2}$ and $120 \mathrm{~g} / \mathrm{m}$ ", respectively.

On the other hand, high moisture was most influential to depress dry matter production of plants grown in PD plot. The lowest dry matter weight was presented in FL-hd and PF-hd plots and the dry matter accumulation during the treatment period of 38 days from Aug. 2 to Sept. 9 was limited to only several grams per $\mathrm{m}^{2}$. When light drought was imposed on plants at pre-flowering stage, it was as effective as heary drought on curbing dry matter production. These plants failed to produce 


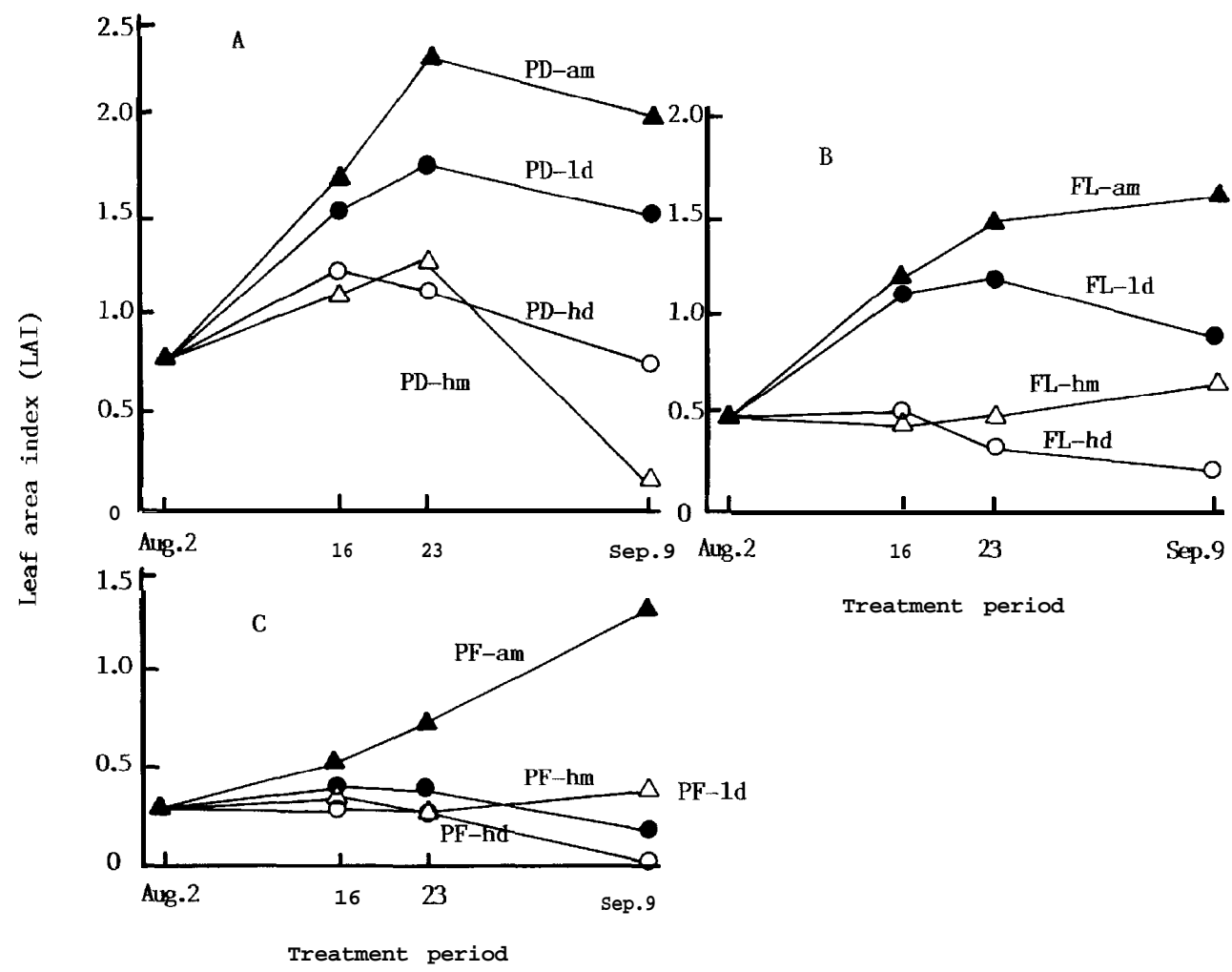

Fig. 2 Time course change in leaf area index of plants grown under different soil moisture conditions.

any flower or pod.

\section{Leaf growth :}

Leaf area index (LAI) in PD plot increased until Aug. 16 or 23, as presented in Fig. 2. Maximum leaf area indexes of plants in PD-am, - ld, -hm and -hd plots were 2.3, 1.7, 1.1 and 1.25, respectively. After that, LAI decreased especially at high moisture and heavy drought. While in F L-am and PF-am plots, LAI increased continuously until the harvest day. Light drought depressed the leaf area of plants grown in PF plot to an exceptionally low level, however, such a severe effect was not found in the other plots. In general, higher dry matter production was given with higher LAI.

\section{Leaf area production rate and crop growth rate :}

Changes in leaf area production rate (LPR) and crop growth rate (CGR) with soil moisture content, and the relationship between LPR and CGR are presented in Fig. 3. CGR presented here is the average value for the whole treatment period from Aug. 2 to Sept. 9. On the other hand, LPR was calculated as the value for the limited period 

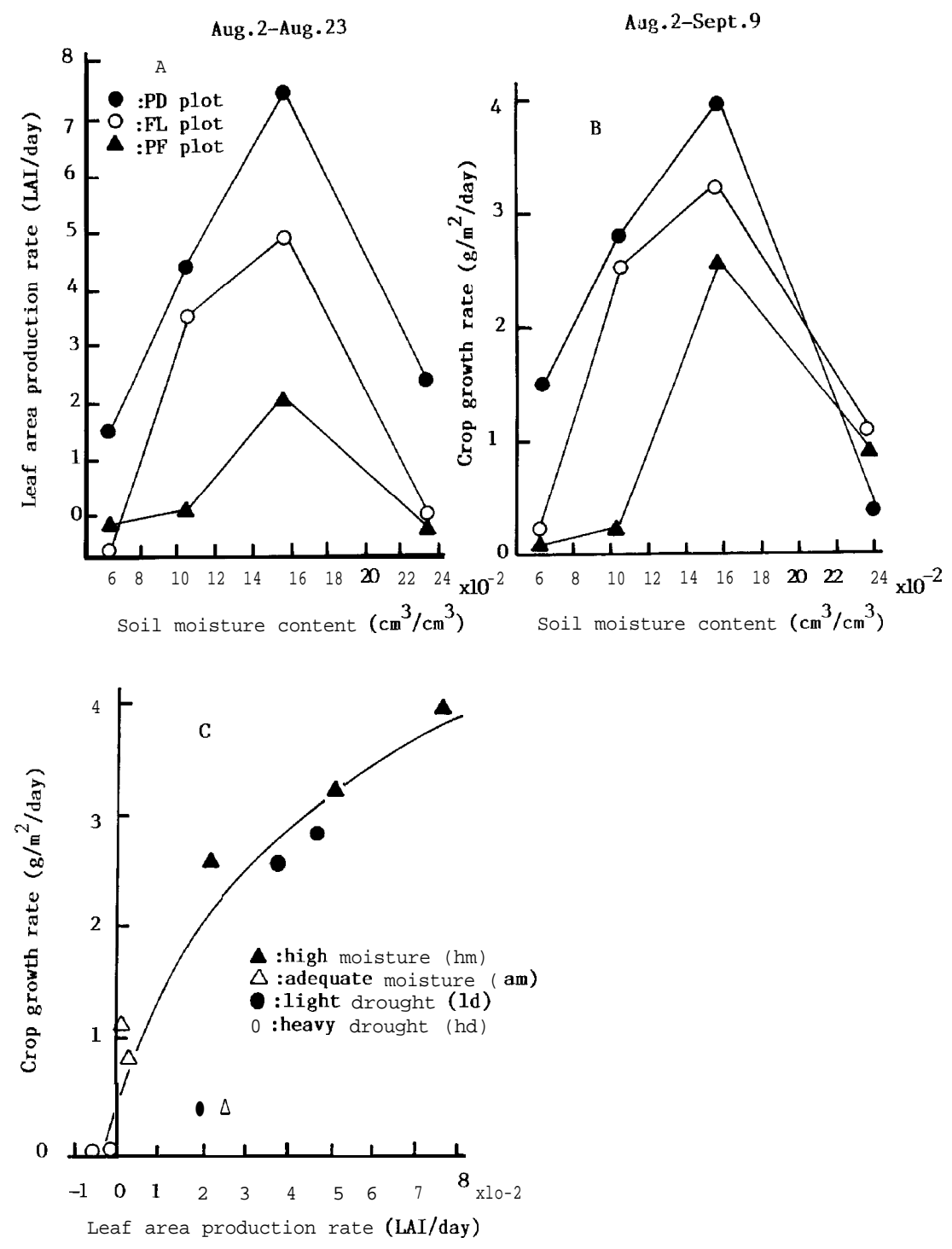

Fig. 3 Relationships between soil moisture content and leaf area production rate(A) and crop growth rate(B). Relationship between leaf area production rate and crop growth rate $(\mathrm{C})$.

from Aug. 2 to Aug. 23, because after Aug. 23 leaf area index decreased rapidly at some treatment plots.

The relationship of optimum curve was found between LPR and soil moisture content (Fig. 3-A). The development of leaf area in FL and PF plots almost stopped when the soil moisture content reduced to around $0.06 \mathrm{~cm}^{3} / \mathrm{cm}^{3}$ or rose to around 0.24 
$\mathrm{cm}^{3} / \mathrm{cm}^{3}$.

The optimum soil moisture content for leaf growth was found to be around 0.15 $\mathrm{cm}^{3} / \mathrm{cm}^{3}$. The highest LPR in PD plot was $0.074 \mathrm{LA} / \mathrm{m}^{2} /$ day, roughly three-fold of that $\left(0.024 \mathrm{LA} / \mathrm{m}^{2} /\right.$ day) in $\mathrm{PF}$ plot.

Fig. 3-B gives the relationship between CGR and soil moisture content. The highest CGRs in PD, FL and PF plots, were $3.97,3.21$ and $2.69 \mathrm{~g} / \mathrm{m}^{2} /$ day, respectively, all of which presented at a soil moisture content of $0.15 \mathrm{~cm}^{3} / \mathrm{cm}^{3}$. Heavy drought and high moisture reduced CGR greatly in the three plots. All the data of CGR and LPR given above were plotted in Fig. 3-C where CGR increased curvilinearly with LPR increase.

Photosynthesis and transpiration :

Fig. 4 shows the effect of soil moisture content on photosynthetic rate. Photosynthetic rates in this figure were presented as the average values measured at each treatment. The highest photosynthetic rate was found in the plants grown at a soil moisture of $0.15 \mathrm{~cm}^{3} / \mathrm{cm}^{3}$. High moisture and heavy drought decreased the photosynthetic rates greatly. The responding trends in photosynthetic rate to soil

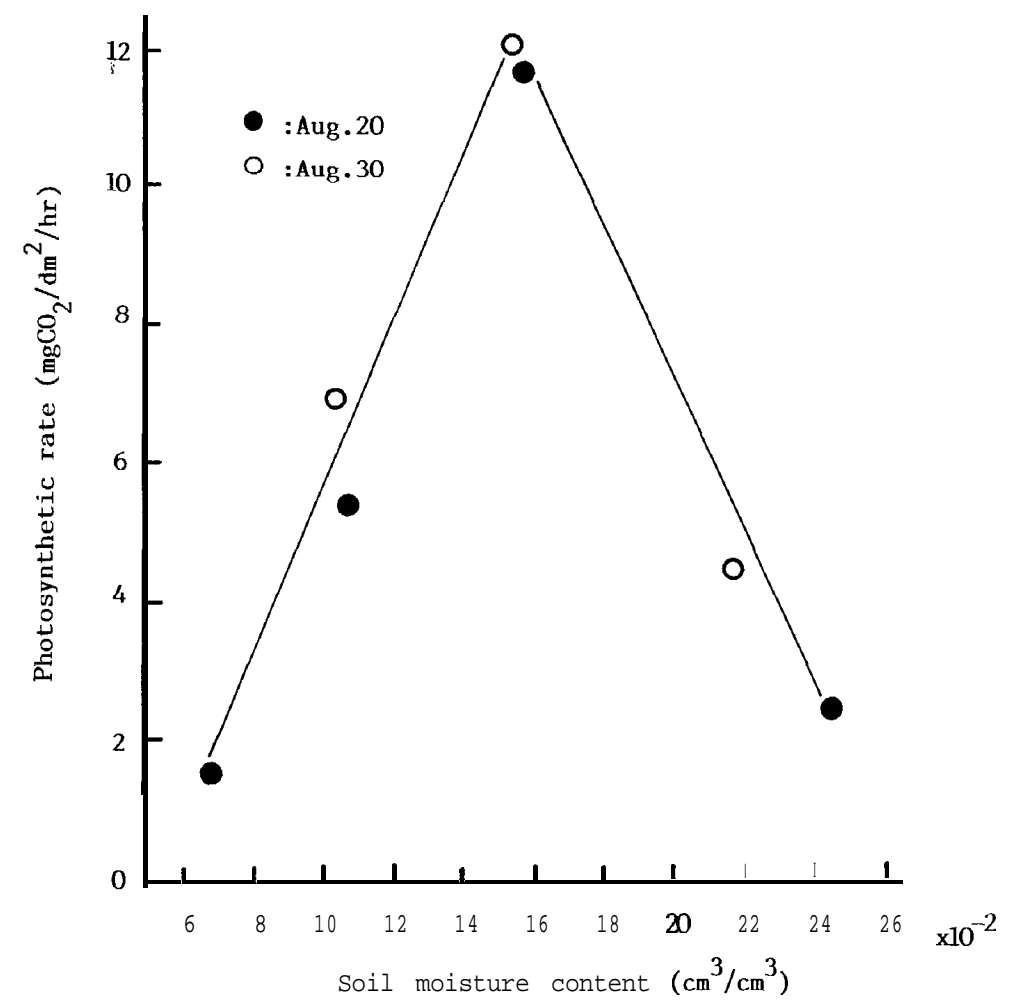

Fig. 4 Relationship between soil moisture content and photosynthetic rate. Measurements were made at a light intensity of over $1000 \mu \mathrm{mol} / \mathrm{m}^{2} / \mathrm{s}$. 
Table 3. Photosynthetic rate, transpiration rate, leaf conductance and water use efficiency at different growth stages in rnungbean plant as influenced by soil moisture.

\begin{tabular}{|c|c|c|c|c|c|c|c|c|}
\hline \multirow[t]{2}{*}{ Treatment plot } & \multicolumn{2}{|c|}{$\begin{array}{c}\text { Photosynthetic } \\
\text { rate } \\
\left(\mathrm{mgCO}_{2} / \mathrm{dm}^{2} / \mathrm{hr}\right)\end{array}$} & \multicolumn{2}{|c|}{$\begin{array}{c}\text { Transpiration } \\
\text { rate } \\
\left(\mathrm{gH}_{2} \mathrm{O} / \mathrm{dm}^{2} / \mathrm{hr}\right)\end{array}$} & \multicolumn{2}{|c|}{$\begin{array}{c}\text { Leaf } \\
\text { conductance } \\
(\mathrm{cm} / \mathrm{sec})\end{array}$} & \multicolumn{2}{|c|}{$\begin{array}{c}\text { Water use } \\
\text { efficiency } \\
\left(\mathrm{mgCO}_{2} / \mathrm{gH}_{2} \mathrm{O}\right)\end{array}$} \\
\hline & Aug. 20 & Aug. 30 & Aug. 20 & Aug. 30 & Aug. 20 & Aug. 30 & Aug. 20 & Aug.30 \\
\hline PD-hm & 6.04 & 4.16 & 7.75 & 2.70 & 0.20 & 0.09 & 0.77 & 1.54 \\
\hline PD-am & 12.44 & 7.72 & 10.48 & 5.62 & 0.70 & 0.12 & 1.19 & 1.37 \\
\hline PD-Id & 5.82 & 5.62 & 5.98 & 3.38 & 0.22 & 0.24 & 0.97 & 1.66 \\
\hline PD-hd & 4.72 & 3.08 & 5.50 & 1.64 & 0.16 & 0.04 & 0.86 & 1.88 \\
\hline Mean & 7.26 & 5.15 & 7.43 & 3.34 & 0.32 & 0.12 & 0.95 & 1.61 \\
\hline FL-hm & 0.18 & 0.56 & 1.68 & 0.52 & 0.03 & 0.02 & 0.11 & 1.07 \\
\hline FL-am & 12.00 & 15.40 & 12.20 & 8.60 & 0.86 & 0.31 & 0.98 & 1.79 \\
\hline FL-ld & 10.60 & 8.88 & 9.22 & 6.10 & 0.36 & 0.18 & 1.15 & 1.46 \\
\hline FL-hd & 0.60 & $\cdots \cdots$ & 2.00 & $\ldots \ldots$ & 0.03 & $\ldots \ldots$ & 0.30 & $\ldots \ldots$ \\
\hline Mean & 5.85 & 8.28 & 6.28 & 5.07 & 0.32 & 0.17 & 0.64 & 1.44 \\
\hline PF-hm & 1.30 & 8.63 & 2.80 & 5.30 & 0.06 & 0.15 & 0.46 & 1.63 \\
\hline PF-am & 10.80 & 12.88 & 10.52 & 7.80 & 0.57 & 0.26 & 1.03 & 1.65 \\
\hline PF-ld & -0.35 & 6.20 & 1.52 & 3.60 & 0.02 & 0.07 & -0.23 & 1.72 \\
\hline PF-hd & -0.86 & ...... & 1.68 & $\ldots \ldots$ & 0.02 & $\ldots \ldots$ & -0.51 & $\ldots \ldots$ \\
\hline Mean & 2.72 & 9.24 & 4.13 & 5.57 & 0.17 & 0.16 & 0.19 & 1.67 \\
\hline
\end{tabular}

* Marks of treatment plot ; refer to Table 1.

moisture content drew mono-peaked curve almost similar in pattern to that of LAR and CGR as mentioned above.

Table 3 gives the rates of photosynthesis and transpiration, leaf conductance and water use efficiency of plants changing with soil moisture level and treatmentconducting growth stage. The highest values of photosynthetic and transpiration rates were given under the adequate moisture condition. Light and heavy drought and high moisture caused appreciable reduction in the activity of photosynthesis and transpiration. Plants subjected to heavy drought at PF and FL stages were so severely wilted that measurements of the photosynthetic rate were impossible.

As compared among the photosynthetic and transpiration rates shown in Table 3, these rates in PD plot were least influenced by soil moisture, while those in FL and PF plots were severely reduced by high moisture and drought. A rapid recovery of photosynthetic activity during ten days from Aug. 20 to Aug. 30 was found in the plants subjected to light drought and high moisture at $\mathrm{PF}$ stage. That is, the photosynthetic rate increased from $-0.35 \mathrm{mg} \mathrm{CO}_{2} / \mathrm{dm}^{2}$. hr to $6.20 \mathrm{mgCO}_{2} / \mathrm{dm}^{2}$. hr and $1.30 \mathrm{mg} \mathrm{CO}$,/ $\mathrm{dm}^{2}$. hr to $8.63 \mathrm{mg} \mathrm{CO} / \mathrm{dm}^{2}$. hr, respectively. Such an adaptability was also presented for the transpiration rate, leaf conductance and water use efficiency.

Mutual relationships between photosynthetic rate and transpiration rate or leaf conductance, and between transpiration and water use efficiency were presented in Fig. 5. Photosynthetic rate had a close relation with transpiration rate (Fig. 5-A). Higher rates of photosynthesis were given with higher transpiration rates and as compared the photosynthetic rates given at the same level of transpiration rate 


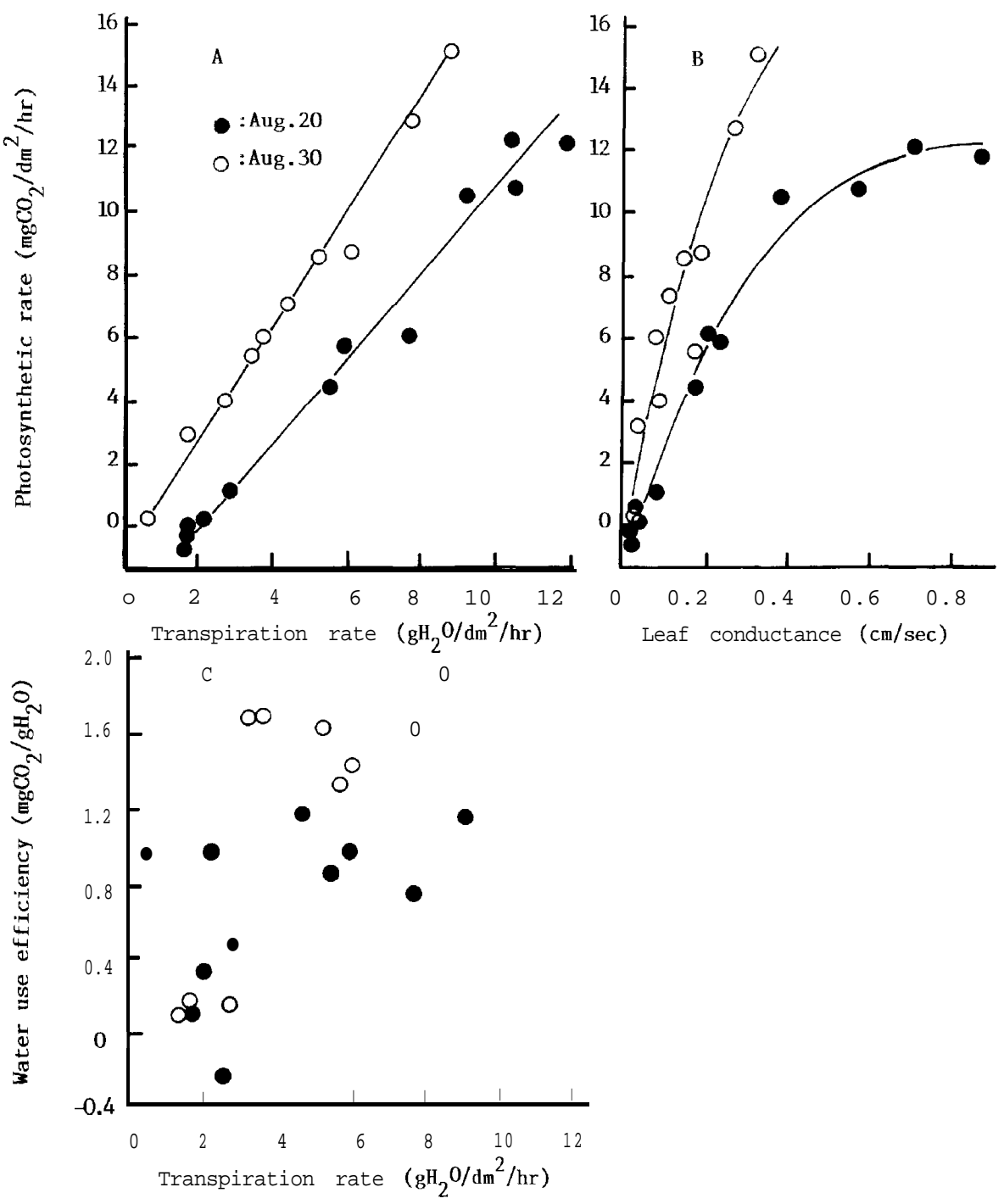

Fig. 5 Relationship between transpiration rate and photosynthetic rate (A), between stomatal conductance and photosynthetic rate (B), and between transpiration rate and water use efficiency(C). Water use efficiency is the ratio of photosynthetic rate/ transpiration rate. The measurements were made at a light intensity over $1000 \mu \mathrm{mol} /$ $\mathrm{m}^{2} / \mathrm{s}$.

between on Aug. 20 and Aug. 30, the latter rates were considerably higher.

As shown in Fig. 5-B, photosynthetic rates related hyperbolically with leaf conductance. For the data of Aug. 20, a saturation point in photosynthetic rate was found at a leaf conductance of $0.7 \mathrm{~cm} / \mathrm{sec}$. The leaf conductances measured on Aug. 30 were 
Table 4. Grain yield and yield components of mungbean plant as influenced by soil moisture.

\begin{tabular}{|c|c|c|c|c|c|}
\hline Treatment plot & $\underset{\left(\mathrm{g} / \mathrm{m}^{2}\right)}{\text { Grain yield }}$ & $\begin{array}{l}\text { Grain yield } \\
(\mathrm{g} / \text { plant })\end{array}$ & $\begin{array}{l}\text { No. of pods } \\
\text { (/plant) }\end{array}$ & $\begin{array}{c}\text { No. of seeds } \\
\text { (/pod) }\end{array}$ & Seed weight \\
\hline PD-hm & 34.3 & 1.04 & 4.1 & 11.3 & 22.4 \\
\hline PD-am & 128.0 & 3.88 & 13.0 & 12.4 & 24.1 \\
\hline PD-ld & 79.2 & 2.40 & 7.4 & 10.9 & 29.8 \\
\hline PD-hd & 39.6 & 1.20 & 4.2 & 10.0 & 28.5 \\
\hline Mean & 70.2 & 2.13 & 7.2 & 11.2 & 26.2 \\
\hline FL-hm & 13.2 & 0.40 & 2.5 & 8.0 & 20.1 \\
\hline FL-am & 119.4 & 3.62 & 12.0 & 11.0 & 25.6 \\
\hline FL-Id & 45.5 & 1.38 & 4.6 & 10.1 & 30.0 \\
\hline FL-hd & 0 & 0 & 0 & 0 & 0 \\
\hline Mean & 44.5 & 1.35 & 4.8 & 7.3 & 18.9 \\
\hline PF-hm & 6.2 & 0.19 & 2.6 & 11.6 & 20.1 \\
\hline PF-am & 101.9 & 3.09 & 11.3 & 11.2 & 24.4 \\
\hline PF-ld & 0 & 0 & 0 & 0 & 0 \\
\hline PF-hd & 0 & 0 & 0 & 0 & \\
\hline Mean & 27.0 & 0.82 & 3.5 & 5.7 & 11.1 \\
\hline
\end{tabular}

as a whole smaller than those on Aug. 20, contrary to this, larger photosynthetic rates were given on Aug. 30.

Water use efficiency was presented as a ratio of $\mathrm{CO}$, weight $(\mathrm{mg})$ in photosynthesis to $\mathrm{H}_{2} \mathrm{O}$ weight $(\mathrm{g})$ in transpiration. Water use efficiency had a rising trend with increase of transpiration rate, although a clear relation did not exist between both parameters (Fig. 5-C).

\section{Seed yield production :}

Yield and the components of yield are presented in Table 4. Average grain yield under the adequate moisture was $116 \mathrm{~g} / \mathrm{m}$ ". Drought and high moisture reduced yields in FL and PF plots but these are relatively less effective in PD plot. Plants experienced water deficits at PF stage failed to survive to produce flowers and no pods could be harvested. High moisture also caused drastic yield reduction especially in PF plot where the grain yield was only $6.2 \mathrm{~g} / \mathrm{m}^{2}$. The yield reduction was caused mainly by pod number decrease.

\section{DISCUSSION}

Mungbean plants were sown on the different days, Jun. 15, 22 and 29, to get the plants having the three different growth stages, pod development, flowering and pre-flowering, on Aug. 2 when the treatments started (Table 1). All the plants, except the plants subjected to severe stress, reached the harvest time on Sept. 9. The four soil moisture levels could be kept almost constant at each designed level (Table 2). The experiment condition set here is regarded as adequate for examining the effect of soil moisture on the growth of mungbean plant. 
Dry matter production was reduced by heavy drought and high moisture (Fig. 1). However, the stress effects were variable depending on the treatment-applied growth stages. For example, light drought in PD and FL plots was less effective. On the other hand, this treatment in PF plot gave a considerably large reduction of dry matter production, and there is no increase in dry matter weight after the start of treatment.

The response trend of leaf area production to soil moisture was roughly similar to that in dry matter weight (Fig. 1 and 2). This means that the dry matter production of mungbean plants is governed by soil moisture through the leaf area production as pointed out by Kriedemann (1986). The values of LAI in PD plot were higher and less influenced by soil moisture. However, high moisture in FL and PF plots decreased LAI greatly after Aug. 23. It may be considered that leaf drop was caused by the promotion of senescence by 0 , deficits in soil.

In this experiment, we could get an optimum soil moisture $\left(15 \mathrm{~cm}^{3} / \mathrm{cm}^{3}\right)$ for CGR, LPR and photosynthesis of mungbean plants. The optimum soil moisture condition can give high dry matter production or CGR through the joint effect of the increase of leaf area and photosynthetic activity.

Photosynthetic rates measured on Aug. 20 were conspicuously reduced by high moisture in PF and FL plots (Table 3). However, ten days after that, the photosynthetic activity of plant in PF plot recovered to a high level. It is considered that the plants at PF stage may have a capacity expanding the new roots around near the soil surface and meet the transpiration demand of plants sufficiently. While the roots in FL plot has grown to a larger system so that the root functional deterioration by 0 , deficits may become severe. In addition, a high transpiration demand at the flowering stage enlarges the damage to the plant growth.

When the treatments were imposed at pod development stage the effect on the rates of photosynthesis and transpiration were relatively small. Plants has grown to the pod development stage may get the highest tolerability to environmental change in mungbean life cycle. Mitra and Ghildiyal (1988) also observed similar phenomenon in mungbean plant.

O'Toole et al. (1977) regarded the three factors, stomatal resistance, mesophyll resistance and ribulose-1, 5 bisphosphate carboxylase activity, as main regulators to the photosynthesis in Phaseolus vulgaris L. As compared at the same level of leaf conductance, the photosynthetic rates given on Aug. 30 were as a whole larger than those of Aug. 20 (Fig. 5-B). This indicates that the photosynthetic function in mesophyll cell of leaf has been activated and the adaptation to soil moisture change would occur in some enzymes related to $\mathrm{CO}$, fixation.

The grain yield of mungbean plants varied complicatedly depending on soil moisture level and treatment-imposed growth stage. There was not so much difference in yield under the adequate moisture condition. Also the difference of soil moisture level in PD plot was less effective on yield, while light and heavy drought in FL and PF plots reduced the grain yield greatly. The plants subjected to light drought recovered quickly in photosynthetic activity, as mentioned above, but had no grain production.

Concerning the yield components we observed such a compensatory mechanism that the number of pods per plant decreased although seeds increased in size. A similar evidence has been previously reported on legume plants grown at tropical and 
sub-tropical areas by Muchow (1985), and also Hamid (1988) has explained this compensatory phenomenon by the theory of sink-source relation in photosynthate transport.

\section{ACKNOWLEDGMENTS :}

We thank Mr. Y. Matsuda of Practical Botany Laboratory for his assistance in growing plants and gas exchange measurements. One of us (A. Hamid) was supported by the Japan International Cooperation Agency (JICA) during his stay in Kyushu University.

\section{REFERENCES}

Agata, W., S. Hakoyama and Y. Kawamitsu 1985 Influence of light intensity, temperature and humidity on photosynthesis and transpiration of Sasa nipponica and Anndinaria pygmaea. Bot. Mag. (Tokyo), $98: 125-135$

Boyer, J. S. 1976 Photosynthesis at low water potentials. Phil. Trans. R. Soc. London, B273 : $501-$ 512

Ehleringer, J. R. and C. S. Cook 1984 Photosynthesis in Encelia farinosa Gray in response to decreasing leaf water potential. Plant Physiol., $75: 688-693$

Ghorashy, S. R., J. W. Pendleton, D. B. Peters, J. S. Boyer and J. E. Beuerlein 1971 Internal water stress and apparent photosynthesis with soybeans differing in pubescence. Agron. J., 63:674-676

Grieu, P., J. M. Guehl and G. Aussenac 1988 The effects of soil and atmospheric drought on photosynthesis and stomata1 control of gas exchange in three coniferous species. Physiol. Plant., $73: 97-104$

Hamid, A. 1988 Nitrogen and carbofuran effects on the growth and yield performance of mungbean (Vigna radiata (L.) Wilczek). J. Agron. \& Crop Sci., 161 : 11-16

Hamid, A., M. L. Banik and A. Hashem 1988 Stand establishment of mungbean in Bangladesh. TVIS News (Taiwan), 3 (2) :21-24

Hsiao, T. C. 1973 Plant responses to water stress. Ann. Rev. Plant Physiol., 24 : 519-570

Johnson, R. R., N. M. Frey and D. N. Moss 1974 Effect of water stress on photosynthesis and transpiration of flag leaves and spikes of barley and wheat. Crop Sci., $14: 728-731$

Kaiser, W. M. 1987 Effects of water deficit on photosynthetic capacity. Physiol. Plant., 71 : 142-149

Kriedemann, P. E. 1986 Stomata1 and photosynthetic limitations to leaf growth. Aust.J. Plant Physiol., $13: 15-13$

Mitra, S. and M. C. Ghildiyal 1988 Photosynthesis and assimilate partitioning in mungbean in response to source-sink alteration. J. Agron. \& Crop Sci., $160: 303-308$

Muchow, R. C. 1985 Phenology, seed yield and water use of grain legumes grown under different soil water regimes in a semi-arid tropical environment. Field crops Res., 11 : 81-97

O'Toole, J. C., J. L. Ozbun and D. H. Wallace 1977 Photosynthetic response to water stress in Phaseolus vulgaris. Physiol.Plant., $40: 111-114$

Rao, N. K. S. and R. M. Bhatt 1988 Photosynthesis, transpiration, stomata1 diffusive resistance, and relative water content of Capsicum (Bell pepper) grown under water stress. Photosynthetica, 22 : 377-382

Schulze, E. D. 1986 Carbon dioxide and water vapor exchange in response to drought in the atmosphere and in the soil. Ann. Rev. Plant Physiol., 37 :247-274

Von Caemmerer, S. and G. D. Farquhar 1981 Some relationships between the biochemistry of photosynthesis and the gas exchange of leaves. Planta, 153:376-387

Wong, S. C., I. R. Cowan and G. D. Farquhar 1979 Stomatal conductance correlates with photosynthetic capacity. Nature, $282: 424-426$ 